\begin{tabular}{|c|c|}
\hline Whit $2 t_{a}, 15,20$ ) ENGINEERING DATA TRANSMITTAL & 1. EDT 626772 \\
\hline
\end{tabular}

\begin{tabular}{|l|l|}
\hline $\begin{array}{l}\text { 2. To: (Receiving Organization) } \\
\text { Distribution }\end{array}$ & $\begin{array}{l}\text { 3. From: (Originating Organization) } \\
\text { TWRS Sys. Eng. \& Integration }\end{array}$ \\
\hline $\begin{array}{l}\text { 5. Proj./Prog./Dept./Div.: } \\
\text { TWRS IRMS, Eng. \& Integration }\end{array}$ & $\begin{array}{l}\text { 6. Design Authority/Design Agent/Cog. Engr.: } \\
\text { L. G. Peck }\end{array}$ \\
\hline 8. Originator Remarks:
\end{tabular}

Release of TWRS Architecture Tree Document

\begin{tabular}{|c|c|c|c|}
\hline $\begin{array}{l}\text { 4. Relat } \\
\text { NA }\end{array}$ & EDT No & & \\
\hline $\begin{array}{l}\text { 7. Purch } \\
\text { NA }\end{array}$ & ase Order & No.: & \\
\hline $\begin{array}{l}\text { 9. Equip } \\
\text { NA }\end{array}$ & Compone & nt No.: & \\
\hline $\begin{array}{l}\text { 10. Syst } \\
\text { NA }\end{array}$ & $\mathrm{m} / \mathrm{B} \mathrm{Idg} / \mathrm{F}$ & cility: & \\
\hline $\begin{array}{l}\text { 12. Majo } \\
\mathrm{NA}\end{array}$ & Assm. D & g. No.: & \\
\hline $\begin{array}{l}\text { 13. Pern } \\
\text { NA }\end{array}$ & it/Permit & pplicatio & No:: \\
\hline $\begin{array}{l}\text { 14. ReqI } \\
\text { NA }\end{array}$ & Jired Resp & nse Dat & \\
\hline (F) & (G) & (H) & (I) \\
\hline $\begin{array}{l}\text { Approval } \\
\text { Desig- } \\
\text { nator }\end{array}$ & $\begin{array}{c}\text { Reason } \\
\text { for Trans- } \\
\text { mittal }\end{array}$ & $\begin{array}{l}\text { Origi- } \\
\text { nator } \\
\text { Dispo- } \\
\text { stion }\end{array}$ & $\begin{array}{c}\text { Receiv- } \\
\text { er } \\
\text { Dispo- } \\
\text { sition }\end{array}$ \\
\hline $\mathrm{NA}$ & 2 & 1. & 1 \\
\hline & & & \\
\hline & & & \\
\hline & & & \\
\hline & & & \\
\hline & & & \\
\hline & & & \\
\hline
\end{tabular}

11. Receiver Remarks:
None

None
4. Related EDT No:
NA
7. Purchase Order No.:
NA
9. Equip./Component No.:
NA

10. System/Bldg./Facility:
NA

NA

13. Permit/Permit Application No.:

NA

4. Required Response Date:

\begin{tabular}{|l|l|}
\hline \multicolumn{2}{|l}{15.} \\
\hline $\begin{array}{c}\text { (A) } \\
\text { Item } \\
\text { No. }\end{array}$ & (B) Document/Drawing No \\
\hline 1 & $\mathrm{HNE}-4208$ \\
\hline & \\
\hline & \\
\hline & \\
\hline & \\
\hline & \\
\hline & \\
\hline
\end{tabular}

16.

DATA TRANSMITTED

\begin{tabular}{|c|l|}
\hline Approval Designator $(F)$ & \\
\hline E,S, Q, D OR N/A & 1. Approval \\
(See WHC-CM-3-5, & 2. Release \\
Sec. 12.7) & 3. Information \\
\hline
\end{tabular}

17.

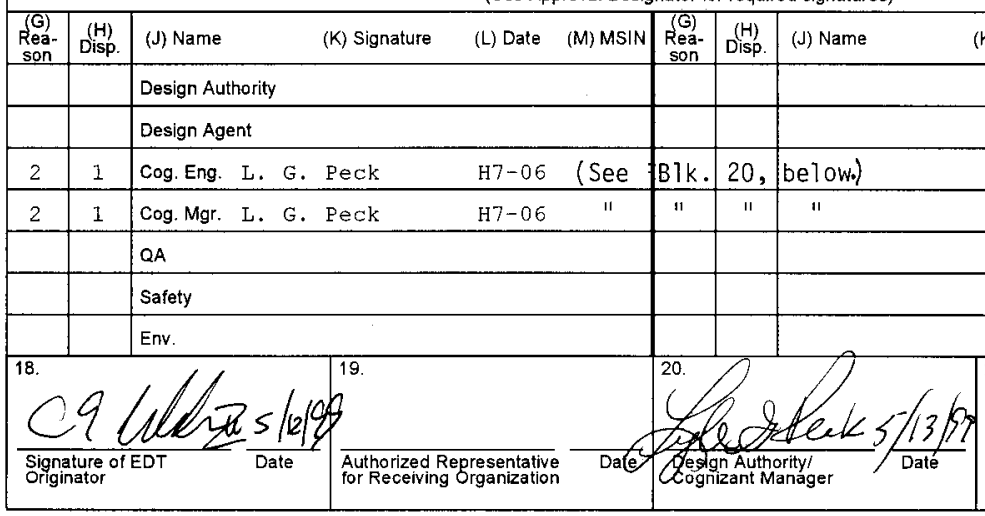

SIGNATURE/DISTRIBUTION
(See Approval Designator for required signatures)

KEY

\begin{tabular}{|l|ll} 
Reason for Transmittal (G) & \multicolumn{2}{|c}{ Disposition $(H) \&(I)$} \\
$\begin{array}{lll}\text { 4. Review } & \text { 1. Approved } & \text { 4. Reviewed no/comment } \\
\text { 5. Post-Review } & \text { 2. Approved w/comment } & \text { 5. Reviewed w/comment } \\
\text { 6. Dist. (Receipt Acknow. Required) } & \text { 3. Disapproved w/comment } & \text { 6. Receipt acknowledged }\end{array}$
\end{tabular}

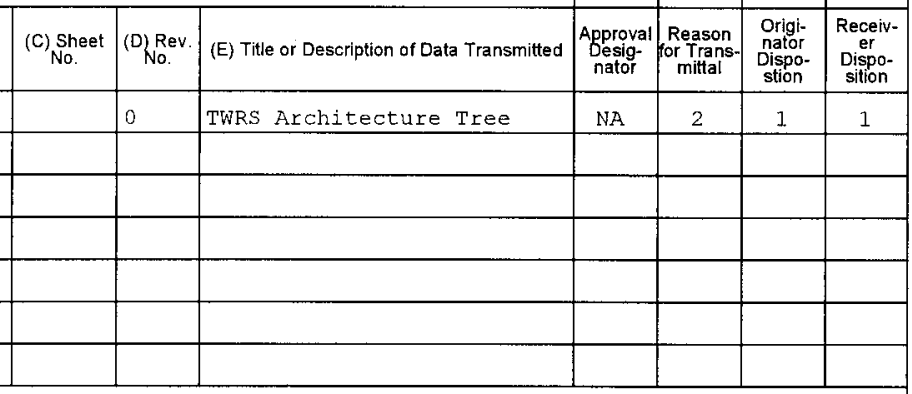




\section{TANK WASTE REMEDIATION SYSTEM ARCHITECTURE TREE}

Lyle G. Peck

Lockheed Martin Hanford Corporation

Richland, WA 99352

U.S. Department of Energy Contract DE-AC06-96RL13200

$\begin{array}{lllll}\text { EDT/ECN: } & 626772 & \text { UC: } 2000 & \\ \text { Org Code: } & 76000 & \text { Charge Code: } 108676 / \text { AR00 } & \text { HN920621 } \\ \text { B\&R Code: } & \text { EW02J1230 } & \text { Total Pages: } 24 \quad 22 & \end{array}$

Key Words: System Architecture, System Engineering, HSTD, Requirements Specification

Abstract: The TWRS Architecture Tree is a hierarchical breakdown to Support the TWRS engineering analysis of the TWRS physical system, including facilities, hardware and software.

TRADEMARK DISCLAIMER. Reference herein to any specific commercial product, process, or service by trade name, trademark, manufacturer, or otherwise, does not necessarily constitute or imply its endorsement, recommendation, or favoring by the United States Government or any agency thereof or its contractors or subcontractors.

Printed in the United States of America. To obtain copies of this document, contact: Document Control Services, P.O. Box 950, Mailstop H6-08, Richland WA 99352, Phone (509) 372-2420; Fax (509) 376-4989.

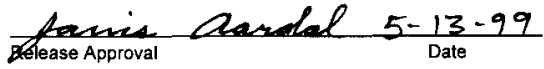

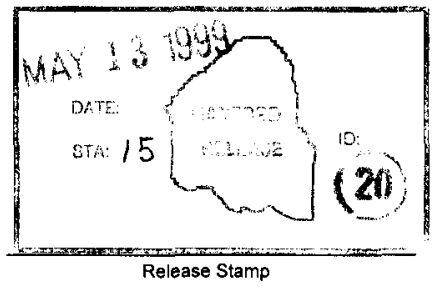

\section{Approved For Public Release}


HNF-4208

Revision 0

\title{
Tank Waste Remediation System Architecture Tree
}

\author{
May 1999
}

Lyle G. Peck

Lockheed Martin Hanford Corporation

Richland, Washington

Brian J. Hende]

TRW

Richland Washington

Prepared for the

U.S. Department of Energy

Richland, Washington 
HNF-4208

Revision 0

\section{Tank Waste Remediation System Architecture Tree}

\begin{tabular}{|c|c|}
\hline 1.1 & $\begin{array}{l}\text { Introduction .......... } \\
\text { Description..... }\end{array}$ \\
\hline 1.2 & Purpose ......... \\
\hline 1.3 & Architecture Tree Benefits.. \\
\hline 1.4 & Basis for TWRS Architecture Tree... \\
\hline 2.0 & TWRS Architecture Tree ....................... \\
\hline & TWRS Architecture Tree. \\
\hline & 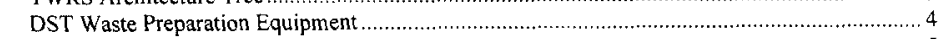 \\
\hline & . \\
\hline & ILAW Disposal System \\
\hline & 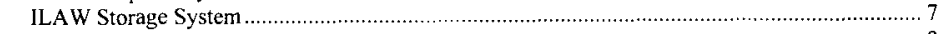 \\
\hline & 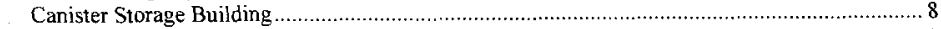 \\
\hline & CSB Support Systems.................................. \\
\hline & 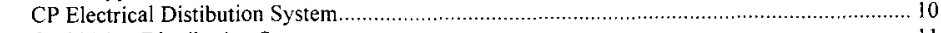 \\
\hline & CP 230 kV Distribution System \\
\hline & CP $230 \mathrm{kV}$ and $13.8 \mathrm{kV}$ Substations \\
\hline & 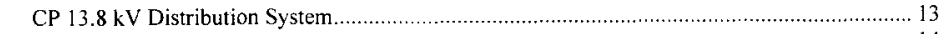 \\
\hline & 等, \\
\hline & CP SCADA FDAS \\
\hline & CP Water Systems \\
\hline & . \\
\hline & 等, \\
\hline & TEDF . \\
\hline
\end{tabular}


HNF-4208

Revision 0

\section{Tank Waste Remediation System Architecture Tree}

\subsection{Introduction}

\subsection{Description}

The TWRS Architecture Tree presented in this document is a hierarchical breakdown to support the TWRS systems engineering analysis of the TWRS physical system, including facilities, hardware and software.

\subsection{Purpose}

The purpose for this systems engineering architecture tree is to describe and communicate the system's selected and existing architecture, to provide a common structure to improve the integration of work and resulting products, and to provide a framework as a basis for TWRS Specification Tree development.

\subsection{Architecture Tree Benefits}

All TWRS development activities should work toward a single integrated view of the TWRS physical system. The TWRS Architecture Tree facilitates this integrated approach by reducing interface problems and conflicts, and by providing a vehicle for allocating requirements throughout the system. It further supports the integration of test and evaluation and related activities, such as technical performance measurement and risk assessment and analysis.

\subsection{Basis for TWRS Architecture Tree}

The TWRS Architecture Tree presented in Section 2 of this document is cross referenced to the Hanford Site Technical Database (HSTD) via the HSTD numbering system and where applicable, the H-14-20000 drawing system identification codes. It is structured to enable the development of specifications by system, and provides trade space for system assessment and alternative generation analyses, by recognizing the existing system and maintaining its functional perspective until architectural decisions are completed. The tank farm portion of the TWRS Architecture Tree is mapped to the existing H-14-20000 drawing system identification codes. The drawing codes are listed below the applicable architecture tree blocks through as an alpha character string. 
HNF-4208

Revision 0

\subsection{TWRS Architecture Tree}

The following pages present the TWRS Architecture Tree, by hierarchical layer, as defined in the HSTD. Each component is described by name and by number. The numbers assigned to each tree component are the "hsems" numbers assigned in the HSTD. These numbers are reflected in the HSTD as, for example, hsems.1.2.3. For brevity sake, the "hsems" prefix to each number was omitted on the tree.

It should be noted that some components are not numbered, indicating that they are not in the HSTD. The data for these components is still in development. 


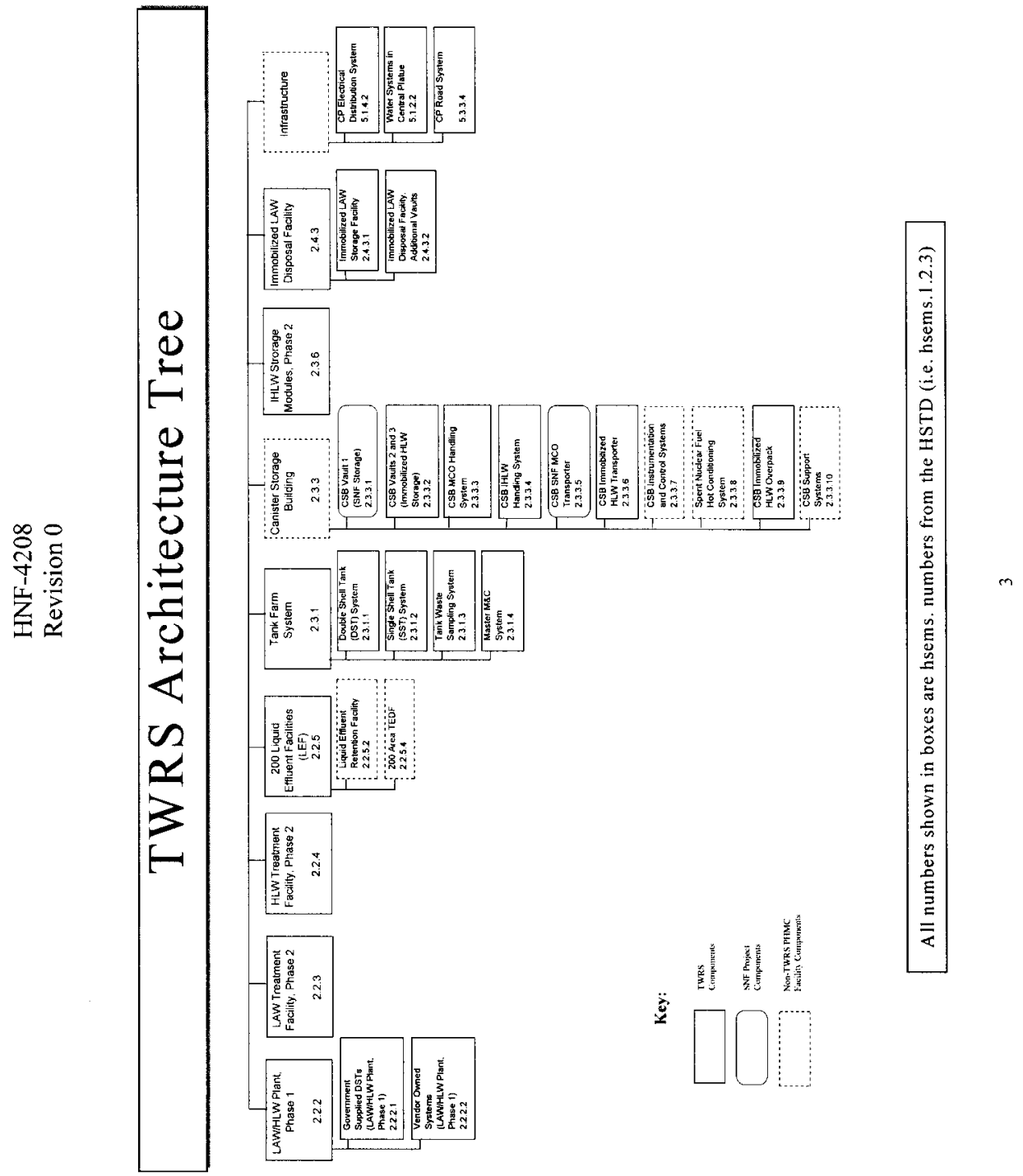



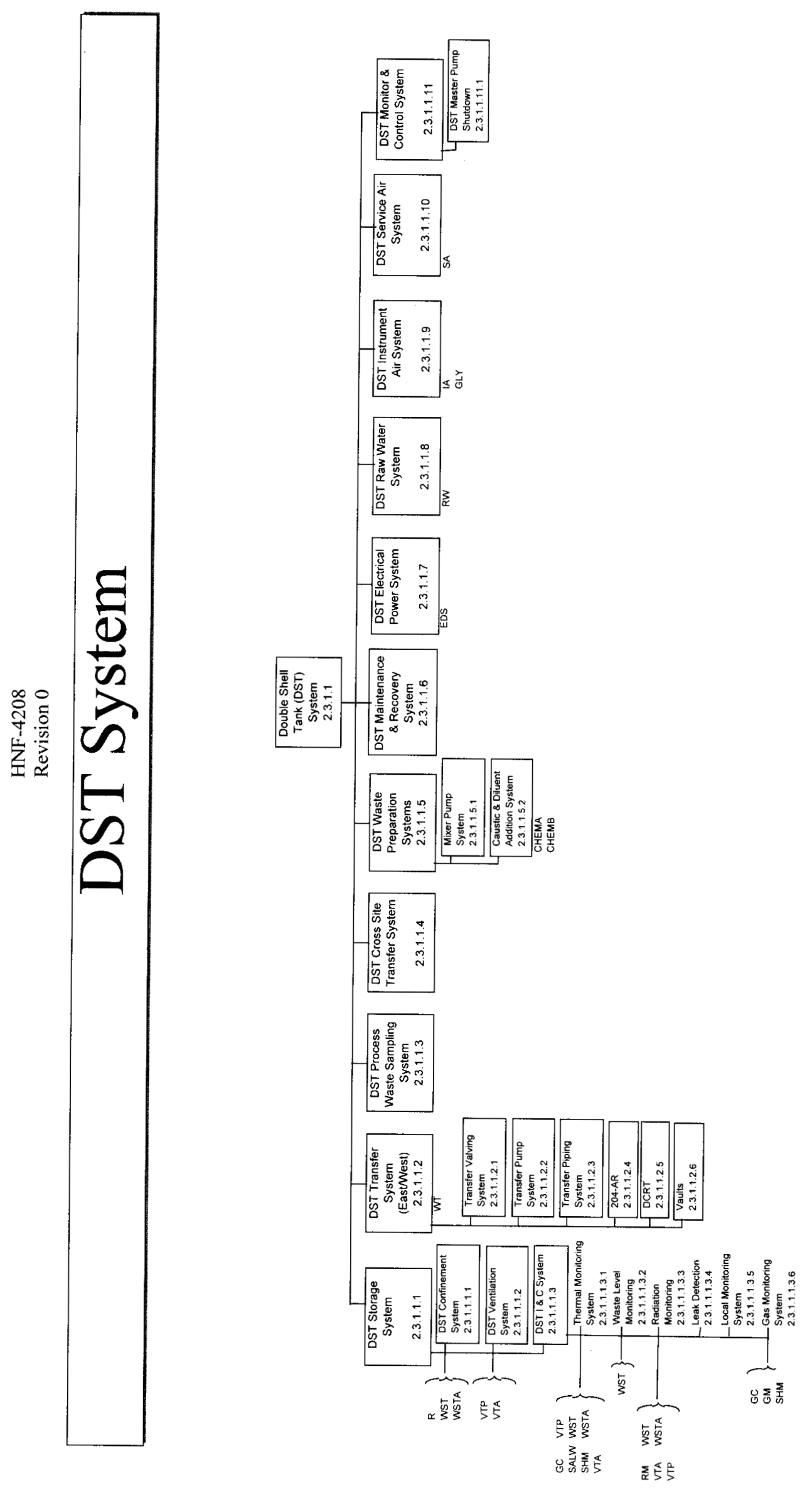

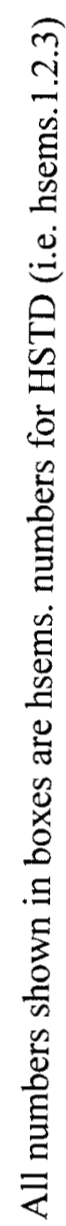




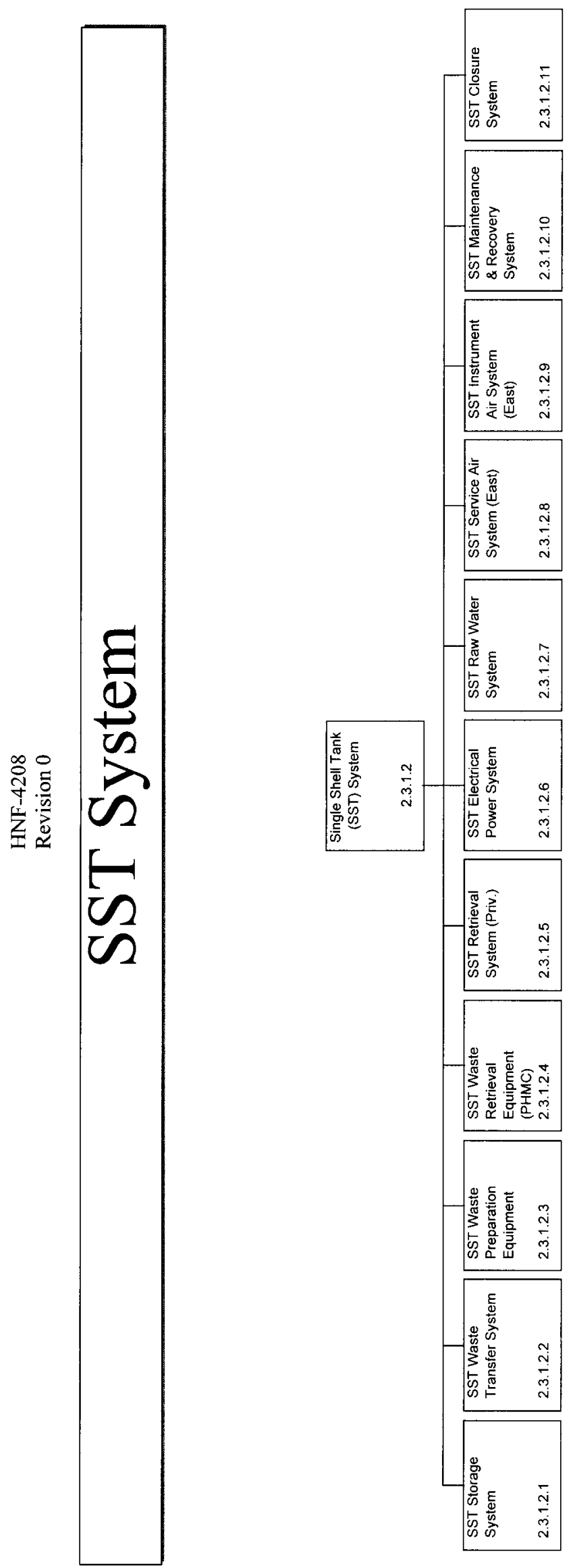

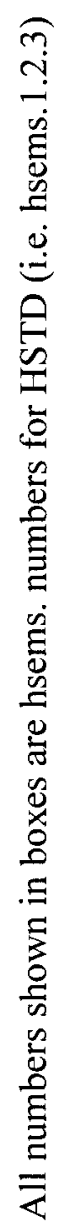

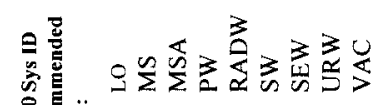



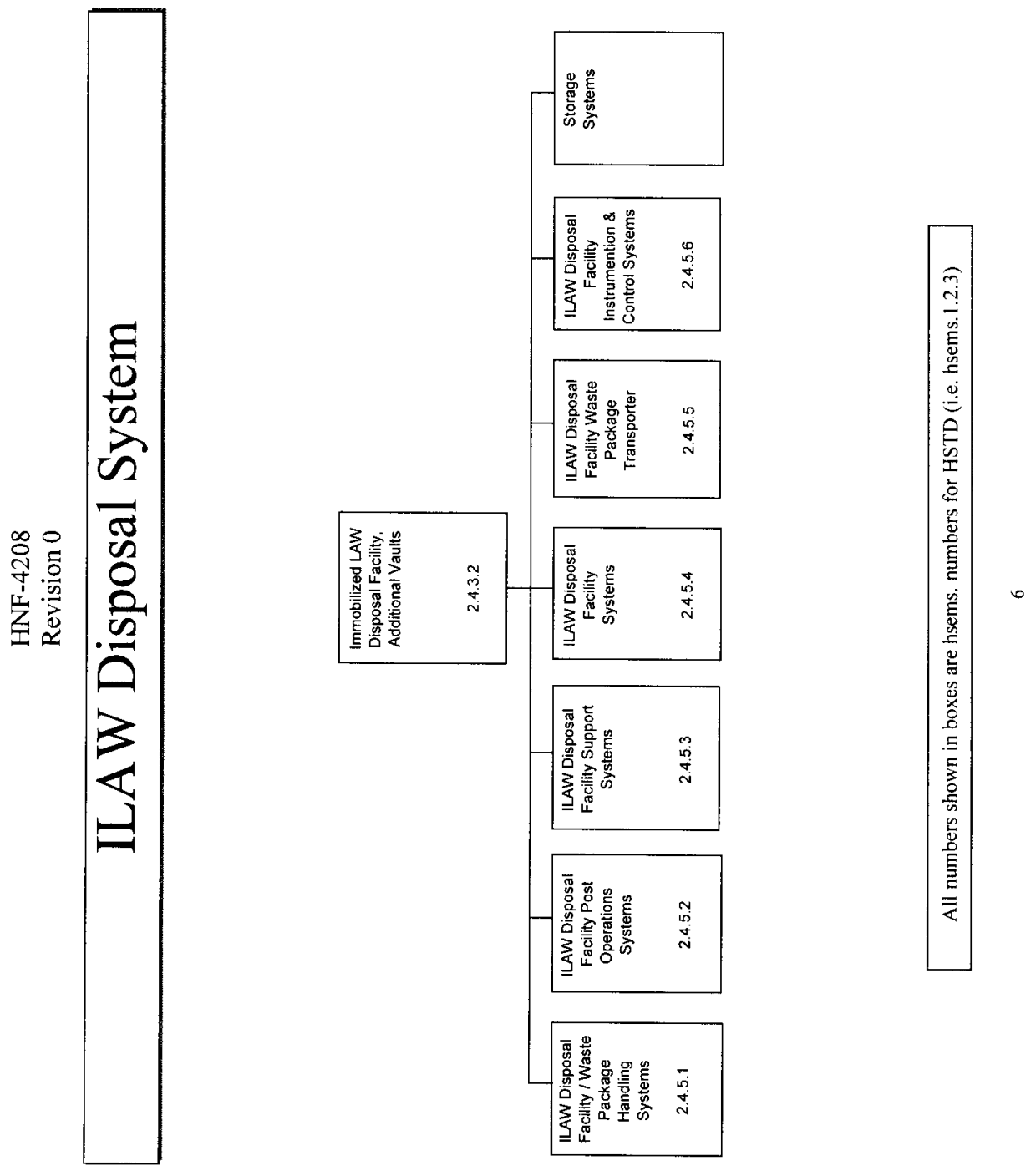

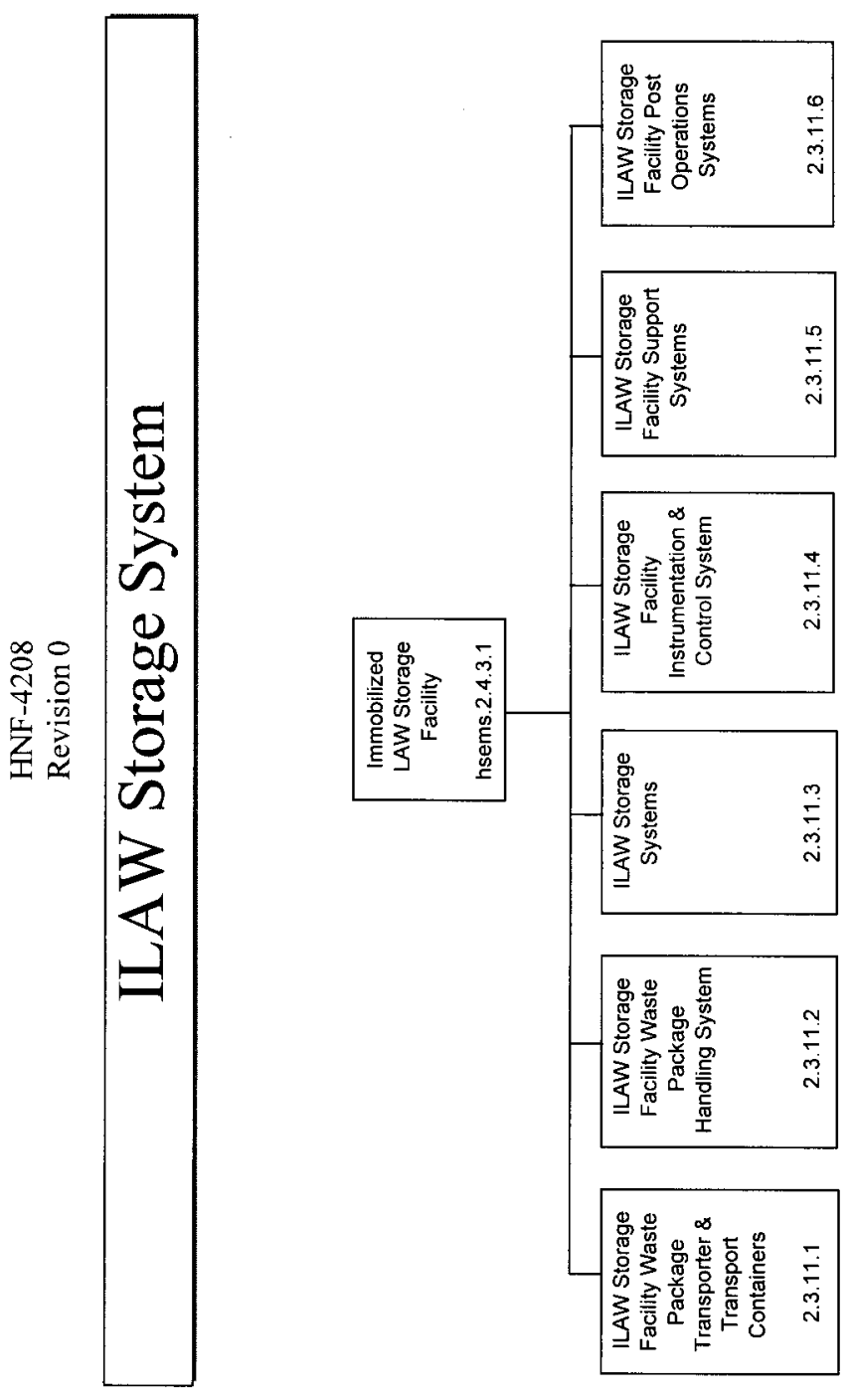

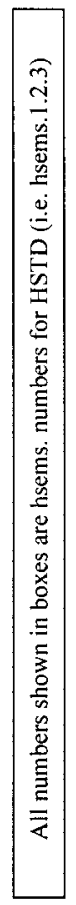




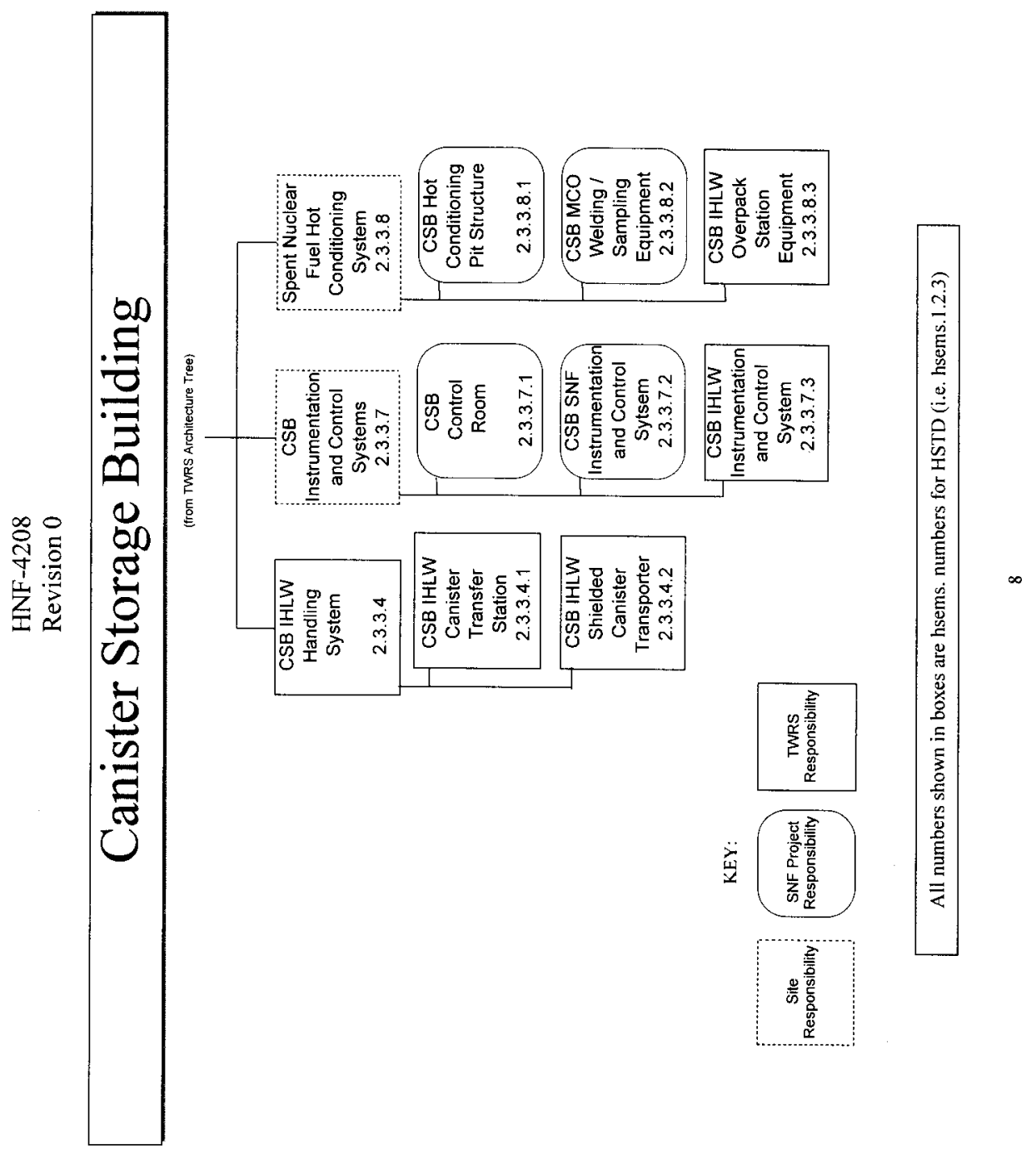



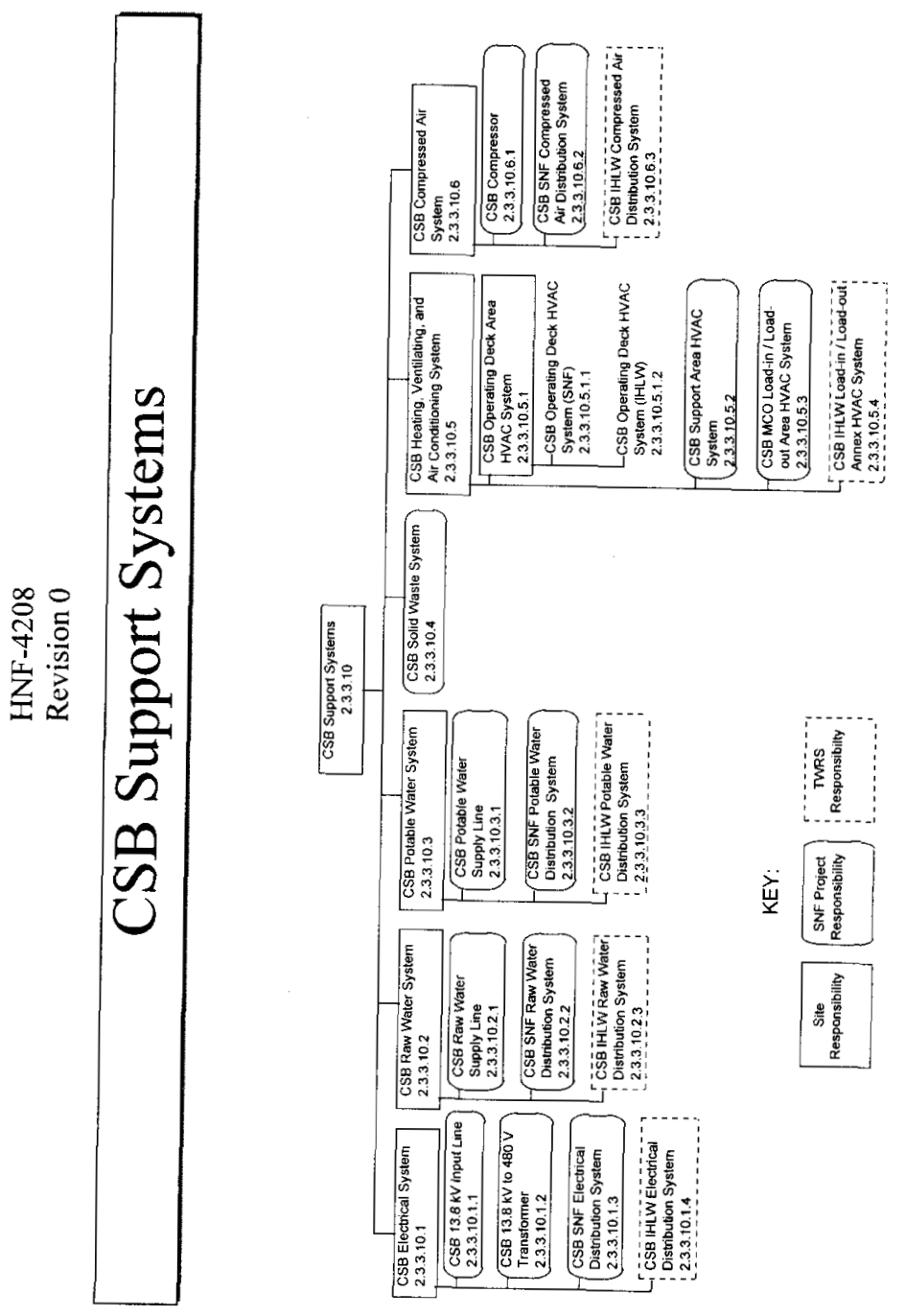

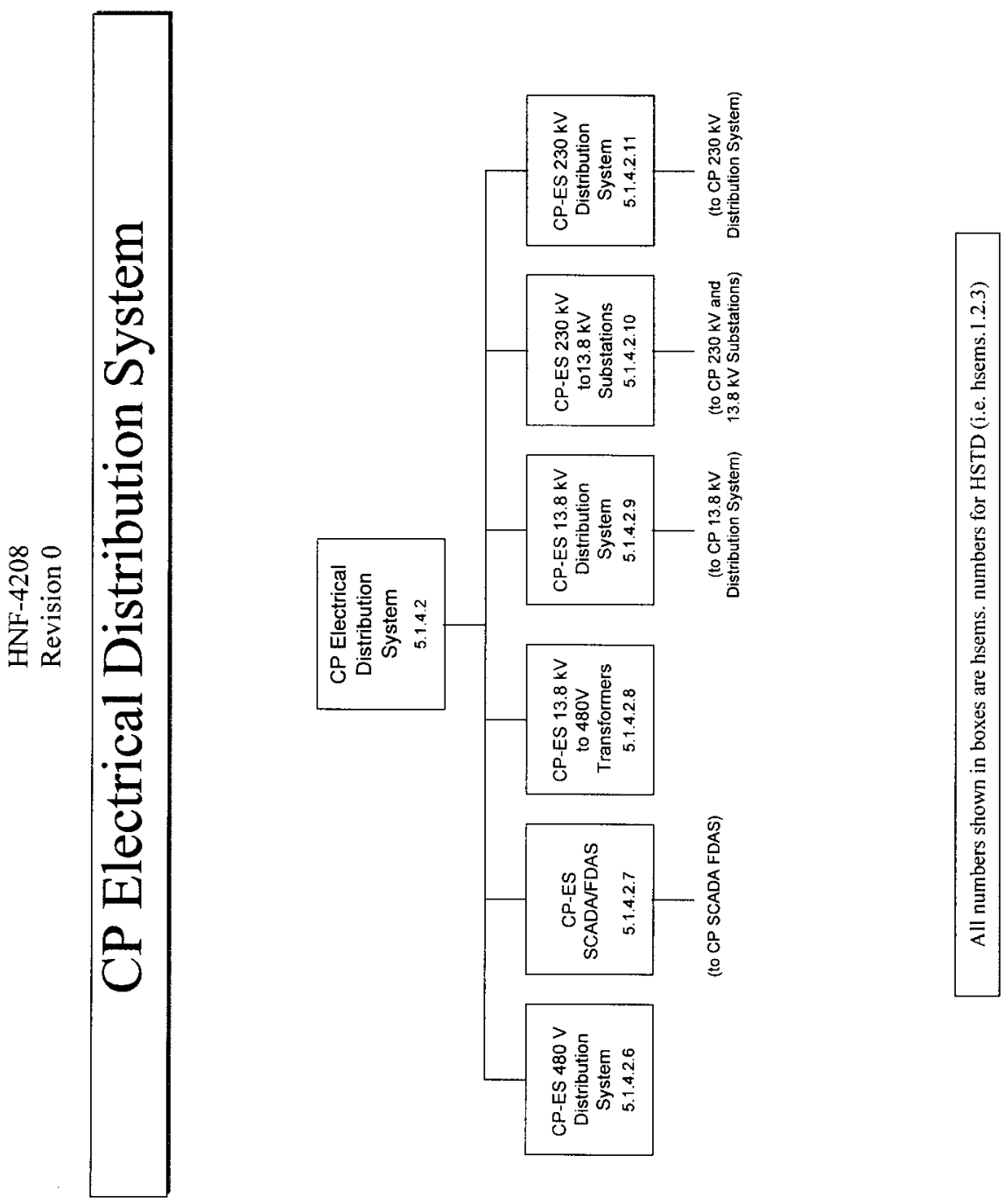


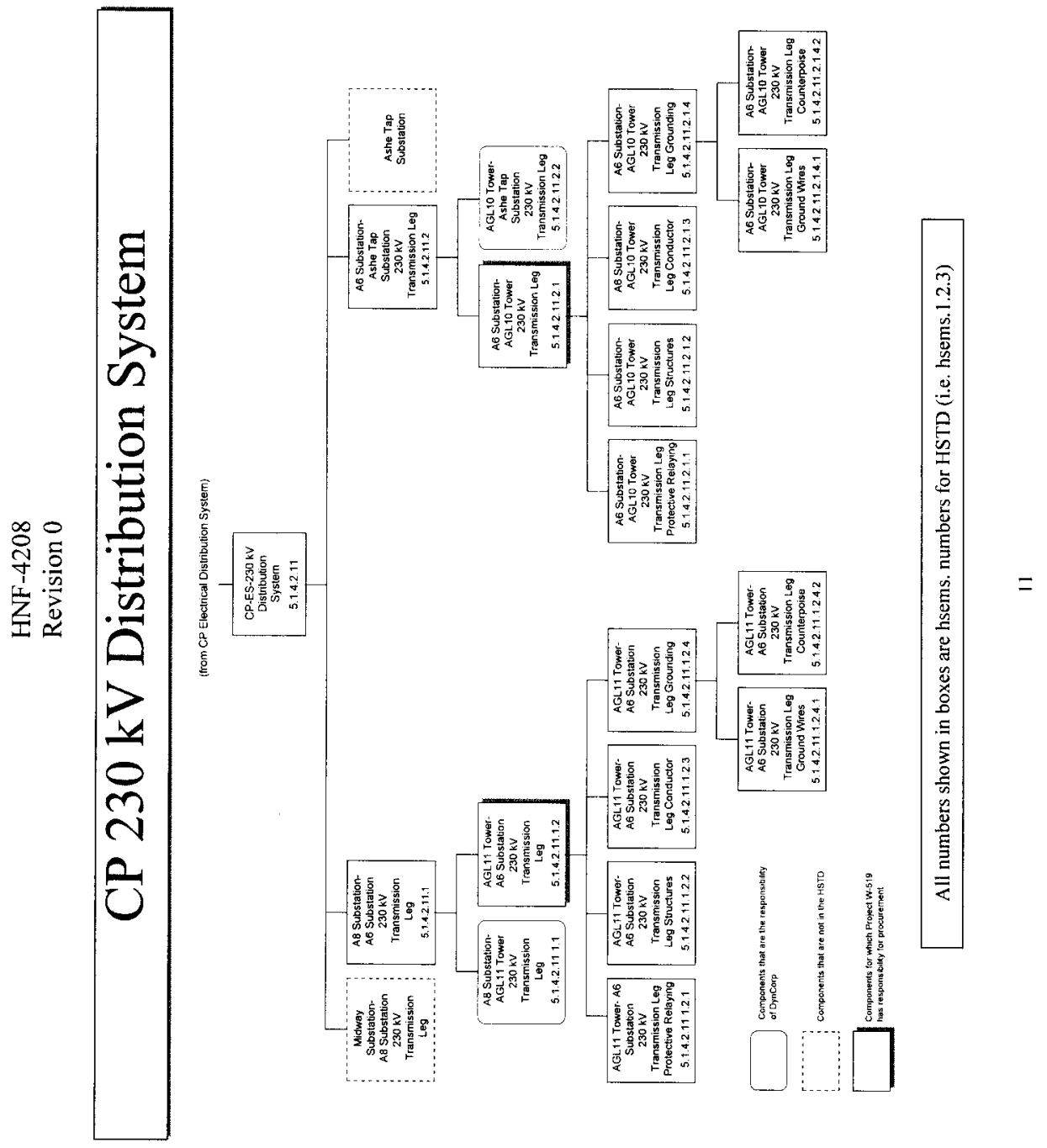




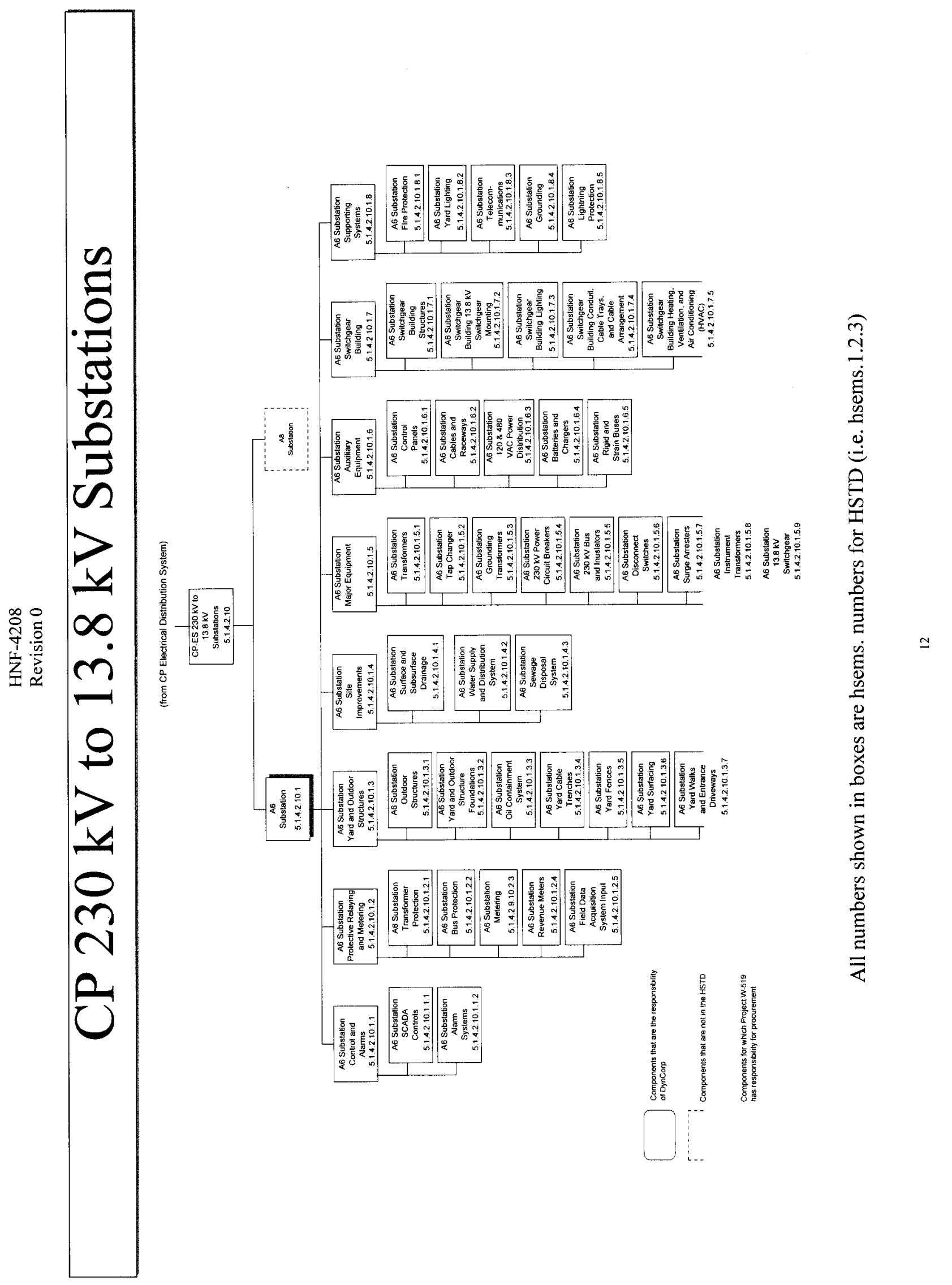




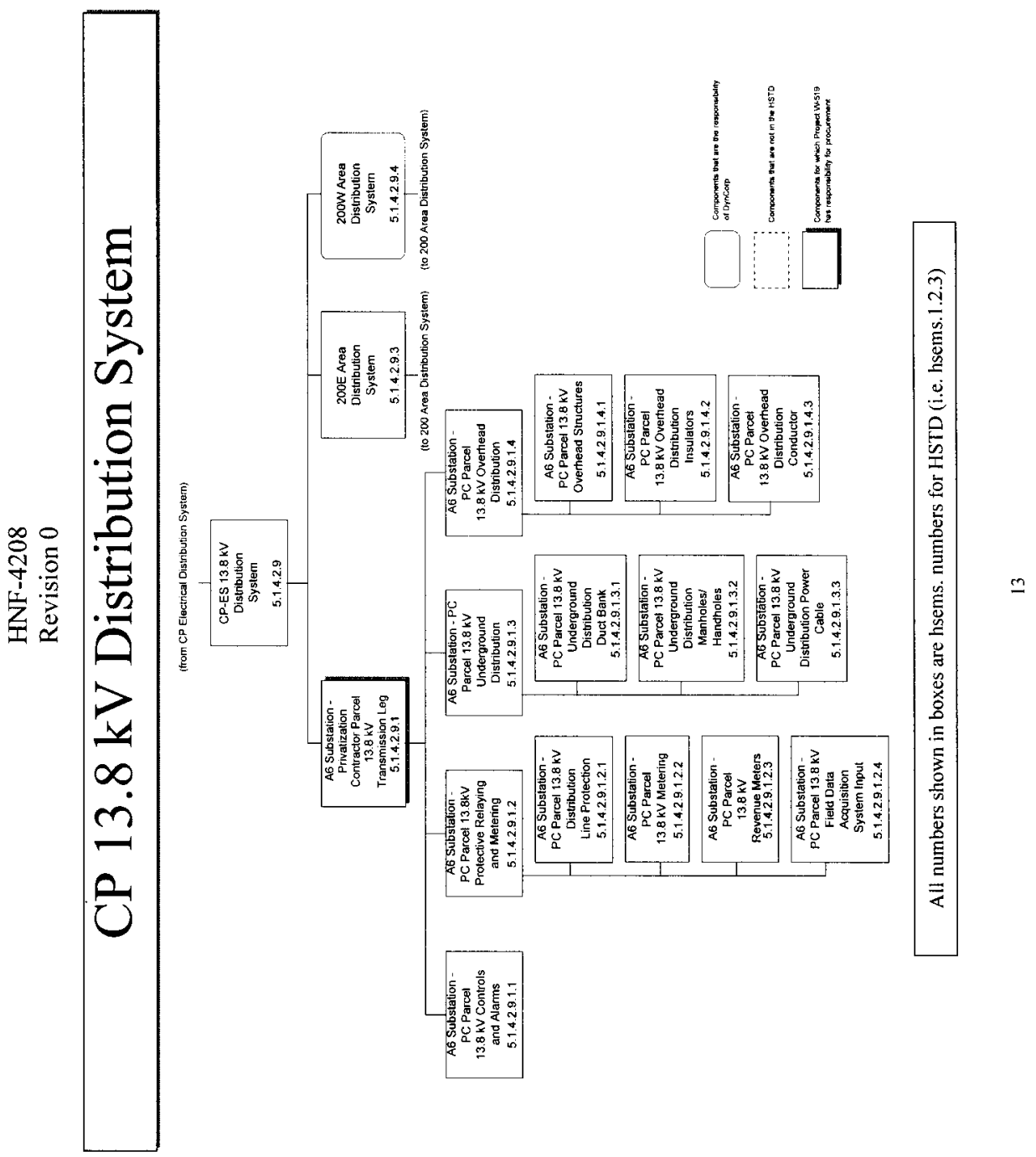



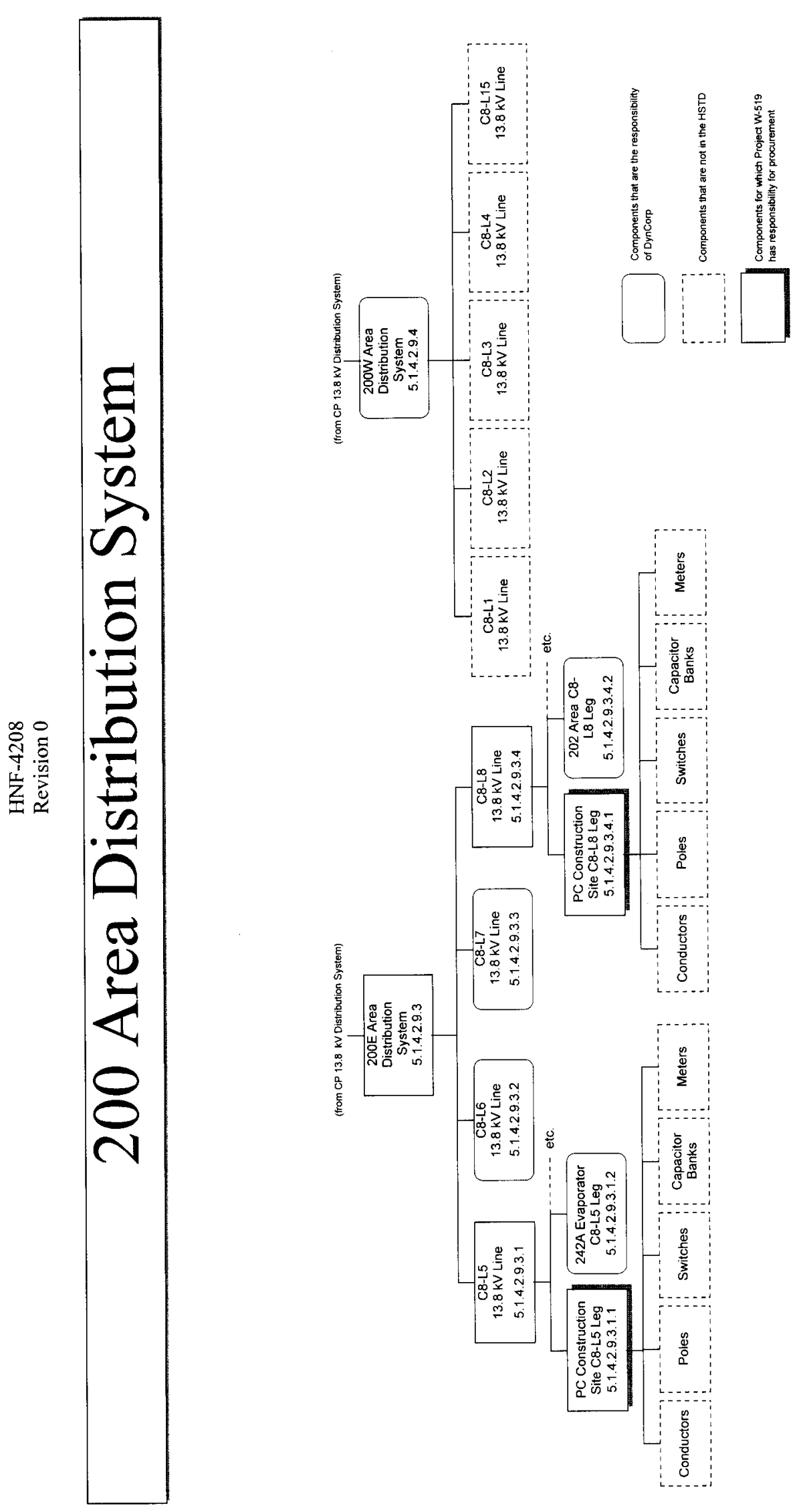

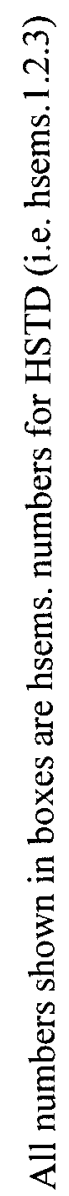




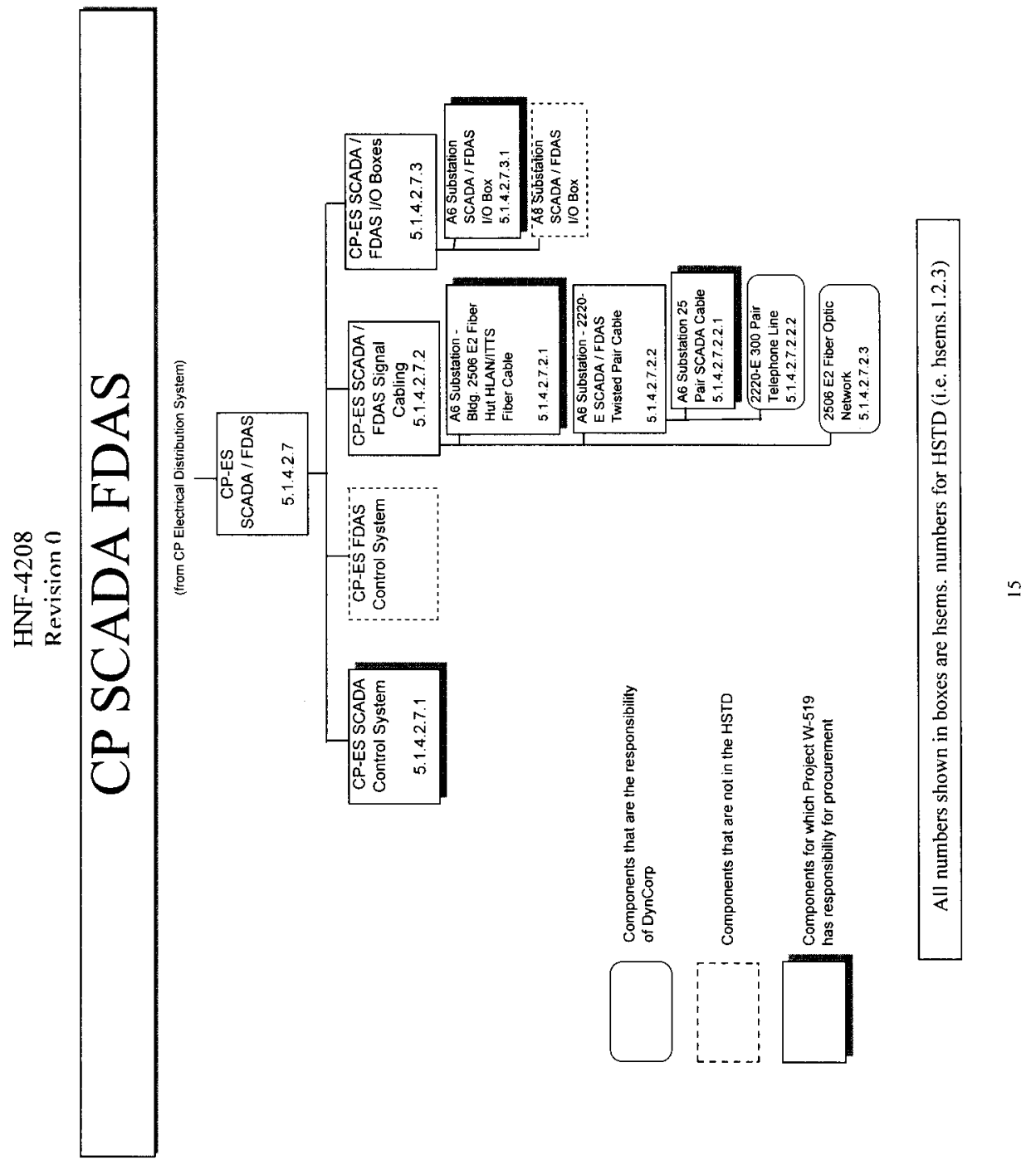




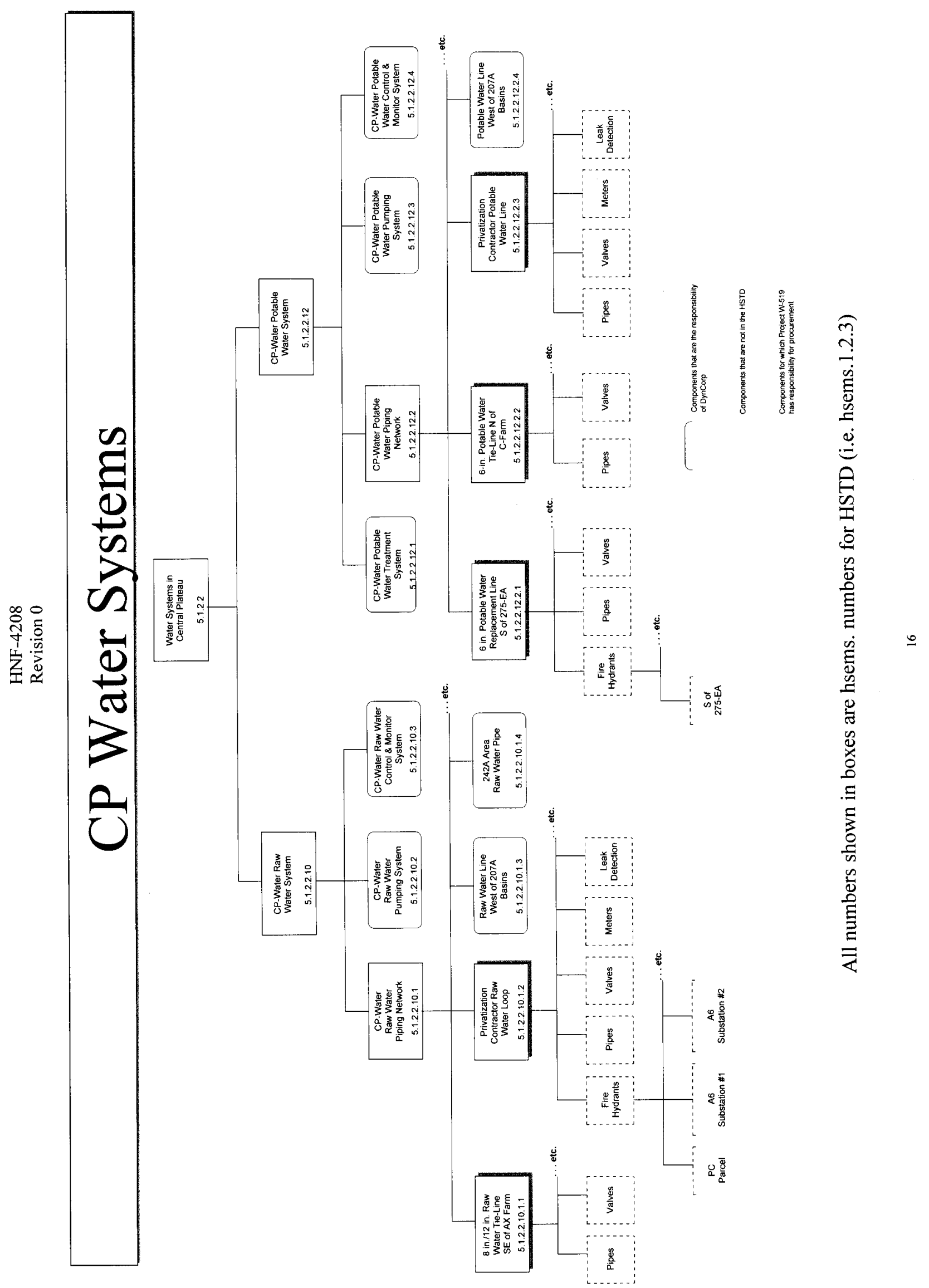



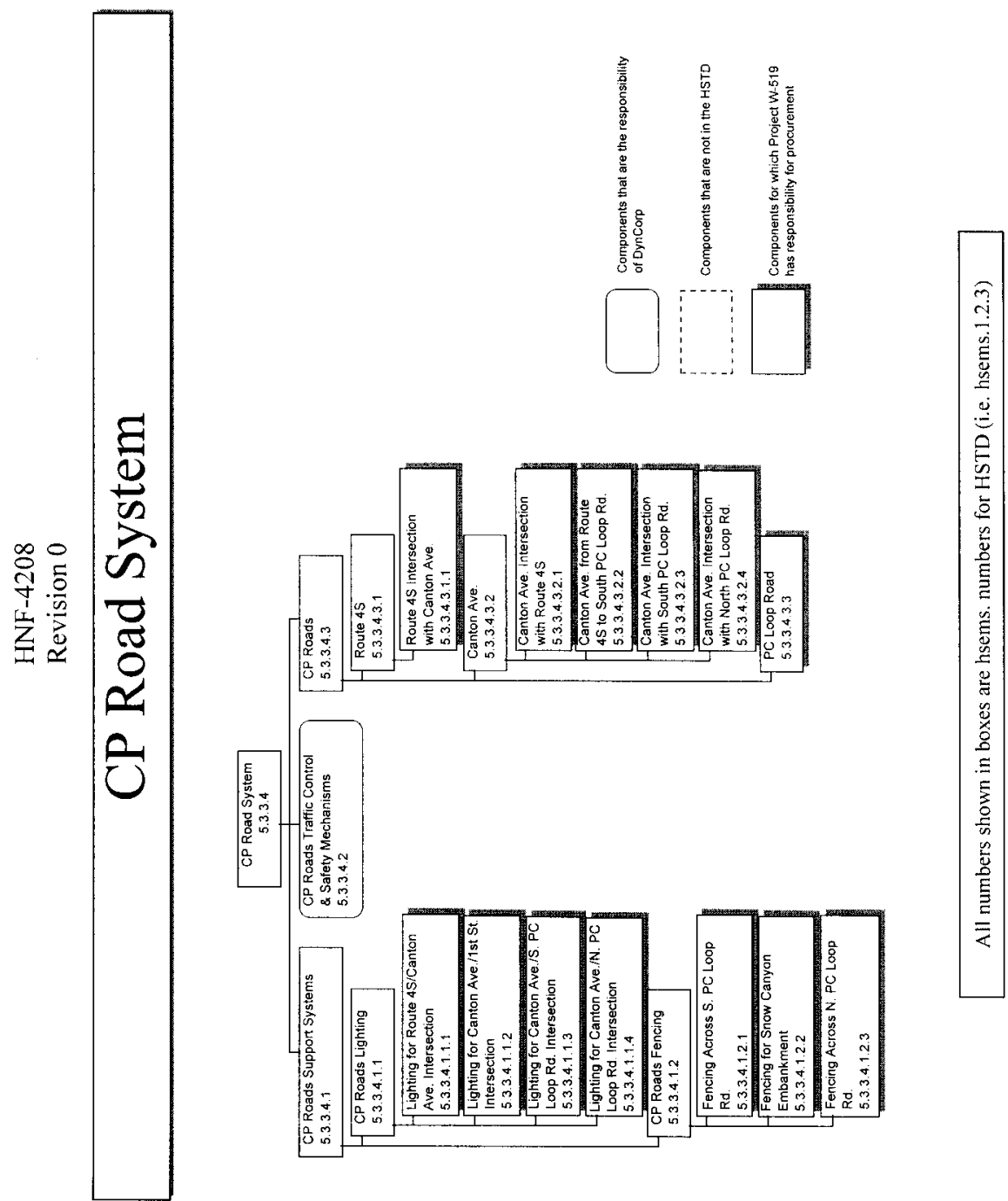

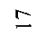




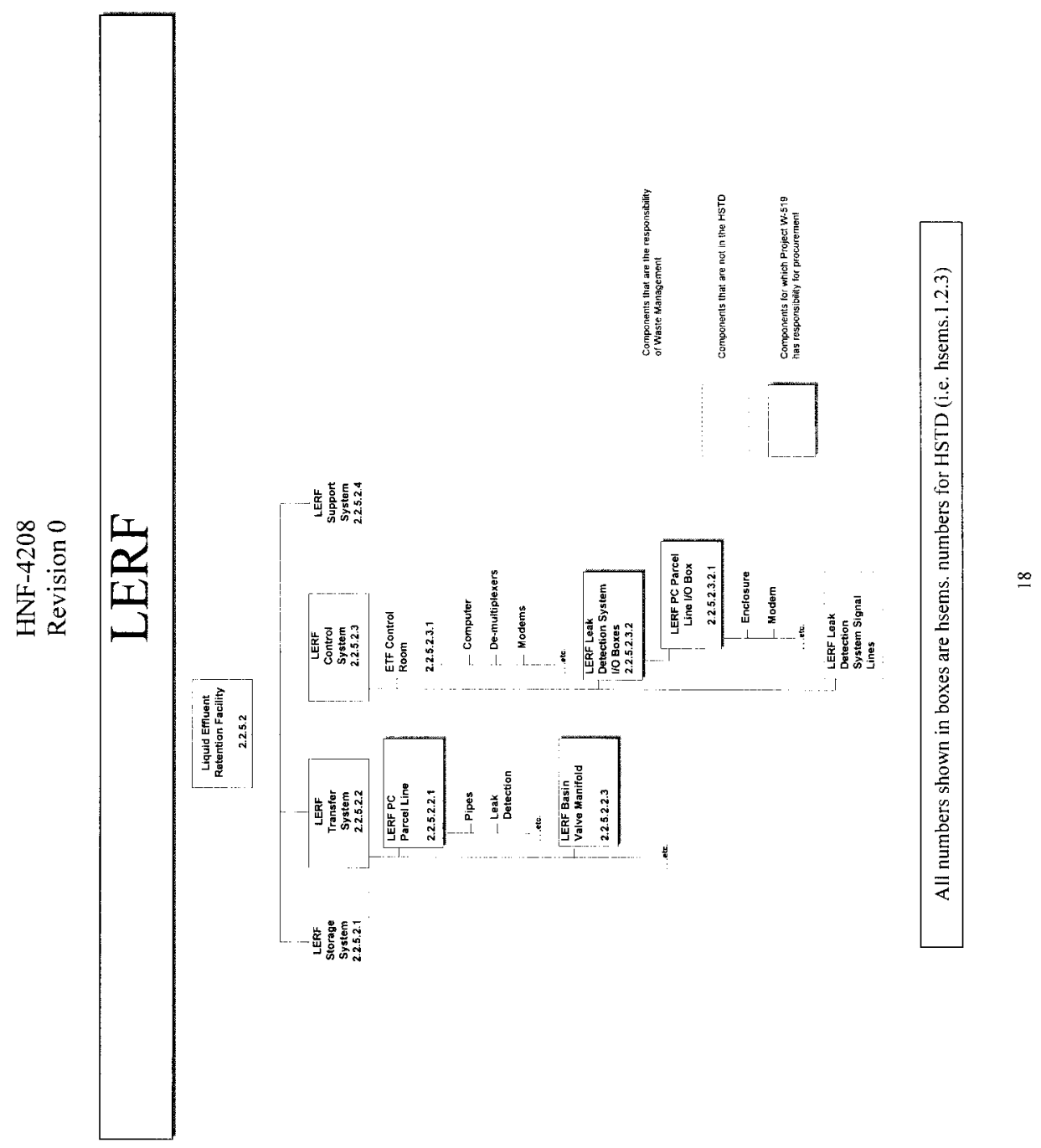



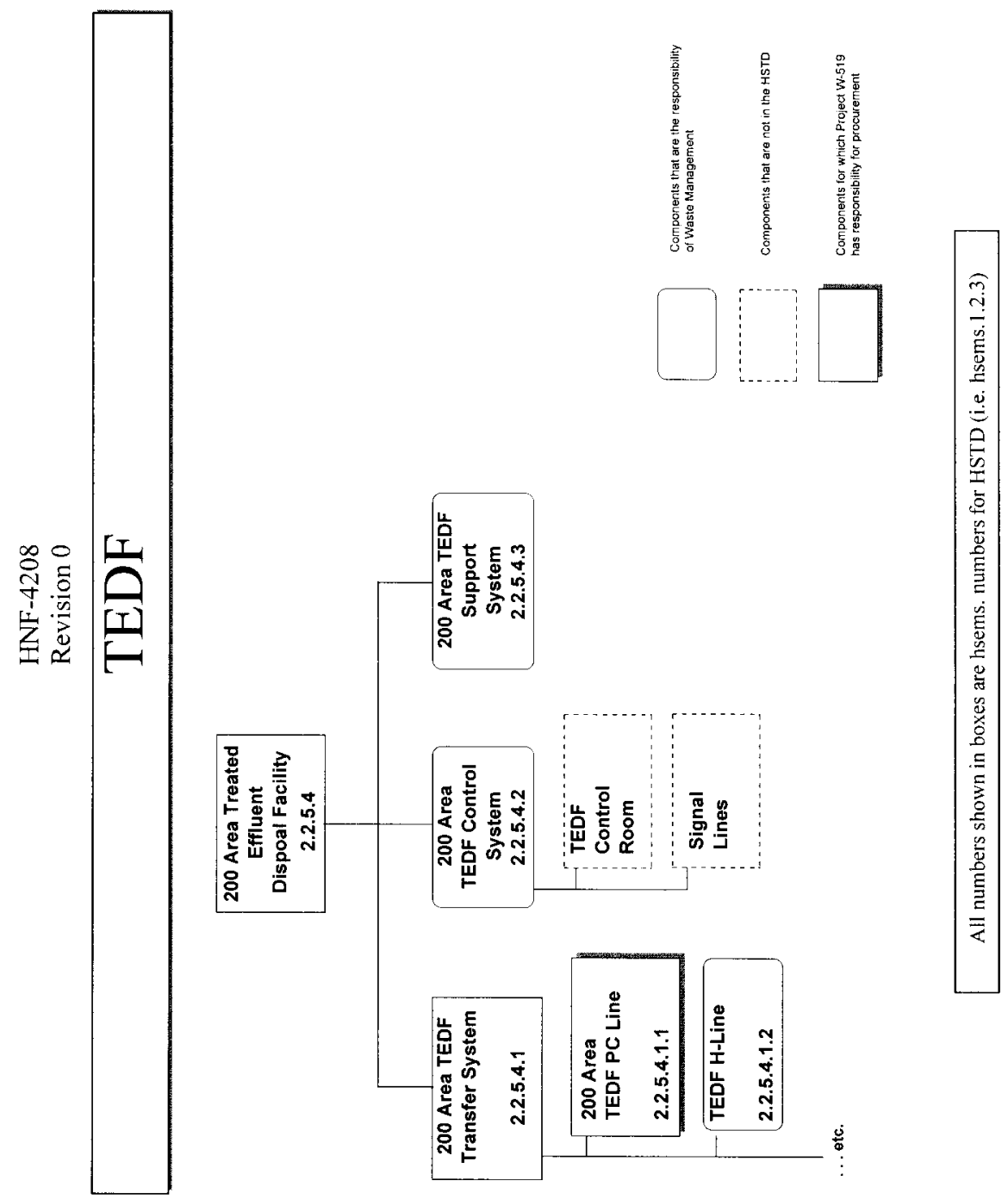

$\underline{-}$ 